\title{
SISTEM INFORMASI PERJALANAN DINAS BERBASIS LOCAL AREA NETWORK (LAN) PADA BADAN PENAGGULANGGAN BENCANA DAERAH (BPBD) PROVINSI KALIMANTAN TIMUR
}

\author{
Ahmad Rofiq Hakim ${ }^{1)}$, Kusno Harianto ${ }^{2)}$, Mega Jiana ${ }^{3)}$ \\ ${ }^{1,2}$ Sistem Informasi, Stmik Widya Cipta Dharma \\ ${ }^{3}$ Sistem Informasi, Stmik Widya Cipta Dharma \\ 1,2,3 J1. Prof. M. Yamin No. 25, Samarinda, 75123 \\ E-mail : rofiq_93@yahoo.com ${ }^{1)}$, kusnoharianto97.kh@gmail.com ${ }^{2)}$,informatikawicida@gmail.com ${ }^{3)}$
}

\begin{abstract}
ABSTRAK
Sistem Informasi Perjalanan Dinas merupakan sistem yang dibangun untuk proses surat perintah perjalanan dinas (SPPD) berupa input data pegawai, kegiatan, penandatangan, transport, biaya.

Penelitian ini dilakukan pada Badan Penaggulanggan Bencana Daerah (BPBD) Provinsi Kalimantan Timur yang beralokasi di Samarinda dengan menggunakan metode penelitian yaitu metode pengumpulan data, studi lapangan, studi pustaka, analisis kebutuhan, desain sistem, dan implementasi sistem. Program yang telah dibangun berjudul Sistem Informasi Perjalanan Dinas Berbasis Jaringan dengan desain sistem mengunakan Flow Of Document (FOD), Data Flow Diagram (DFD), dan Entity Relationship Diagram (ERD) ERD.

Aplikasi Ini dibangun menggunakan software yaitu Foxpro 9.0, database yang digunakan MYSQL. Sistem yang dibangun beroperasi pada Sistem Operasi Windows. Dari hasil implementasi sistem, dapat disimpulkan bahwa dengan penggunaan software dapat membantu bagian rekam medis dalam mengelola rekam medis pasien pada Badan Penaggulanggan Bencana Daerah (BPBD) Provinsi Kalimantan Timur.
\end{abstract}

Diharapkan program ini dapat dikembangkan berbasis web, sehingga dapat di akses secara luas dan penggunaan dana perjalanan dinas jadi lebih transparan

Kata Kunci : Sistem Informais, Perjalanan Dinas, LAN

\section{PENDAHULUAN}

Penggunaan komputer sebagai salah satu alat teknologi informasi sangat dibutuhkan keberadaannya hampir disetiap aspek kehidupan, termasuk dilingkungan instansi pemerintahan.

Penggunaan perangkat komputer sebagai perangkat pendukung manajemen dan pengolahan data adalah sangat tepat dengan mempertimbangkan kuantitas dan kualitas data, dengan demikian penggunaan perangkat komputer dalam setiap informasi sangat mendukung sistem pengambilan keputusan.

Badan Penaggulanggan Bencana Daerah (BPBD) Prov. KalTim merupakan instansi pemerintah yang bertugas melakukan koordinasi ketika terjadinya bencana diwilayah KalTim, dalam aktifitasnya perjalanan dinas menjadi hal utama dalam melaksanakan tugas pokok dan fungsi instansi ini, sehingga membuat laporan perjalanan dinas menjadi hal utama sekaligus kendala karena pengelolaan data perjalanan dinas, masih dilakukan dengan menggunakan aplikasi $M s$-Word dan Ms-Excel, sehingga di dalam menghasilkan seluruh laporan,masih belum akurat dan relatif lama menyelesaikan laporan yang di hasilkan.

Data-data yang berhubungan dengan perjalanan dinas Badan Penaggulanggan Bencana Daerah Daerah (BPBD) yang terhimpun itu, tentu saja sangat diperlukan untuk memenuhi kebutuhan dalam pencarian informasi dan laporan bagi pegawai. Sehingga dibutuhkan suatu sistem informasi yang dapat diandalkan untuk mengolah data menjadi informasi yang bermanfaat dalam mengambil keputusan manajemen baik rutin maupun strategis.

Keadaan ini mendorong suatu usaha untuk merancang suatu sistem informasi perjalanan dinas, agar masalah pengelolaan data perjalanan dinas dapat berjalan dengan baik.

\section{RUANG LINGKUP PENELITIAN}

Dalam penelitian ini permasalahan mencakup

1. Cakupan Masalah

Permasalahan yang terjadi pada Badan Penaggulanggan Bencana Daerah (BPBD) Prov. KalTim adalah dalam pengolahan data untuk bagian pendataan dan biaya masih belum terhubung sehingga bagian rekam medis masih menginputkan data pasien. Berdasarkan penelitian dan pengkajian yang penulis lakukan terhadap permasalahan yang ada, maka penulis mencoba merancang suatu sistem yaitu Sistem Informasi Rekam Medis Pasien Rawat Jalan yang diharapkan dapat membantu bagian pendaftaran dalam mengelolah hasil pemeriksaan kunjungan pasien.

2. Batasan-batasan penelitian Mengingat luasnya ruang lingkup permasalahan yang ada, maka perlu diberikan batasan 
masalah hanya pada Sistem Informasi Perjalanan Dinas Berbasis Local Area Network (LAN) Pada Badan Penaggulanggan Bencana Daerah (BPBD) Provinsi Kalimantan Timur yaitu:

1. Berbasis LAN (Local Area Network)

2. Multi User

3. Rencana hasil yang didapatkan

Aplikasi Sistem Informasi Perjalanan Dinas

Berbasis Local Area Network (LAN) Pada Badan Penaggulanggan Bencana Daerah (BPBD) Provinsi Kalimantan Timur Berbasis Jaringan.

\section{BAHAN DAN METODE}

\subsection{Penjelasan Bahan}

Sistem adalah kumpulan dari komponen-komponen yang dihubungkan dengan berbagai macam interaksi atau antara hubungan yang secara kolektif bereaksi terhadap rangsangan atau kebutuhan dan memenuhi suatu tujuan atau fungsi (Jogiyanto, 2005)

Informasi dapat diibaratkan sebagai darah mengalir di dalam tubuh manusia, seperti halnya informasi didalam sebuah perusahaan sangat penting untuk mendukung kelangsungan bagi perusahaan. Akibat bila kurang mendapatkan informasi, dalam waktui tertentu perusahaan akan mengalami ketidakmampuan menggontrol sumber daya, sehingga dalam mengambil keputusan-keputusan strategis sangat terganggu, pada akhimya akan mengalami kekalahan dalam bersaing dengan lingkungan pesaingnya (Jogiyanto, 2005).

Sistem Informasi adalah Sekumpulan prosedur organisasi pada saat dilaksanakan akan memberikan informasi bagi pengambil keputusan dan untuk mengendalikan organisasi (Jogiyanto, 2005)

Perancangan sistem dapat menentukan bagaimana mencapai sasaran telah ditetapkan, ini melibatkan perangkat lunak dan komponen perangkat keras sistem dengan demikian setelah pemasangan, sistem akan memenuhi spesikasi dibuat pada akhir fase analisis sistem. Aspek lebih lanjut dari perancangan sistem adalah pembentukan sistem sehingga dapat diterima oleh penguna sistem atau operator. Jika sistem dirancang tidak dapat memenuhi spesifikasi dibuat dan tidak dapat diterima oleh penguna atau operator, maka kegiatan analisis sistem harus dimulai dari awal dan spesikasi sistem harus dimodifikasi (Jogiyanto, 2005).

Jaringan lokal atau Local Area Network adalah sekumpulan dua atau lebih komputer yang berada dalam batasan jarak lokasi satu dengan yang lain, yang saling terhubung langsung atau tidak langsung. LAN dibedakan atas cara komputer tersebut saling terkoneksi, baik secara logik maupun fisik. Local Area Network digunakan untuk menghubungkan komputer-komputer pribadi dengan workstation dalam suatu perusahaan yang menggunakan peralatan secara bersama-sama dan saling bertukar informasi.(Suarna 2007).

Database adalah kumpulan fakta-fakta sebagai representasi dari dunia nyata yang saling berhubungan dan mempunyai arti tertentu, database digunakan untuk menyimpan data agar data tersebut dapat dimanipulasi dengan mudah, terjamin keakuratannya, efesien dalam penyimpanan, dan tentu saja dapat dengan mudah untuk diakses kembali (Sutedjo, 2002).

Menurut Arif (2004) Visual FoxPro adalah bahasa pemrograman berbasiskan prosedur yang pertama kali dikembangkan oleh Fox Technologies pada awal 1984. Program ini di kembangkan untuk menyaingi dBaseII. Dalam perkembangannya FoxPro tetap mempertahankan kemampuan pemrograman prosedural dan di lengkapi dengan pemrograman berorientasi objek

\subsection{Metode}

Model Air Terjun (Waterfall) adalah untuk membantu mengatasi kerumitan yang terjadi akibat proyek-proyek pengembangan perangkat lunak. Seperti pada gambar 2.15, sebuah model Air Terjun memacu tim pengembang untuk merinci apa yang seharusnya perangkat lunak lakukan (mengumpulkan dan menentukan kebutuhan sistem) sebelum sistem tersebut dikembangkan (Simarmata, 2010).

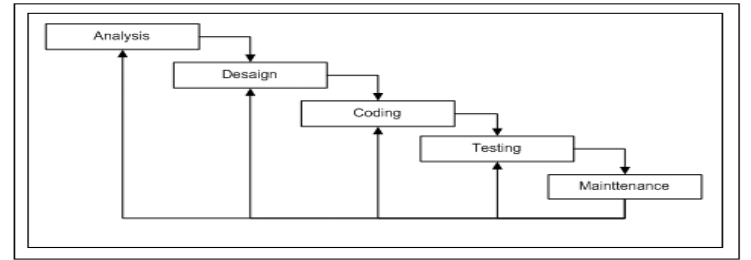

Gambar 1. Model Pengembangan Air Terjun

\section{RANCANGAN SISTEM/APLIKASI}

1. Flow Of Document (FOD) Yang Berjalan

Pegawai membuat Telaahan Staf untuk melaksanakan kegiatan sesuai Dokumen Pelaksanaan Anggaran, kemudian surat Telaahan Staf dan DPA diberikan kepada bagian Keuangan.Pada bagian keuangan Surat Telaahan Staf dan DPA diproses menggunakan microsoft office excel untuk pembuatan SPT dan SPPD SPT dan SPPD kemudian diarsipkan oleh bagian keuangan. SPT dan SPPD dari bagian keuangan kepada pejabat Pengguna Anggaran untuk disahkan dan ditandatangani. SPT dan SPPD yang telah sah kemudian diserahkan kepada pegawai yang selanjutnya akan melakukan perjalanan dinas.

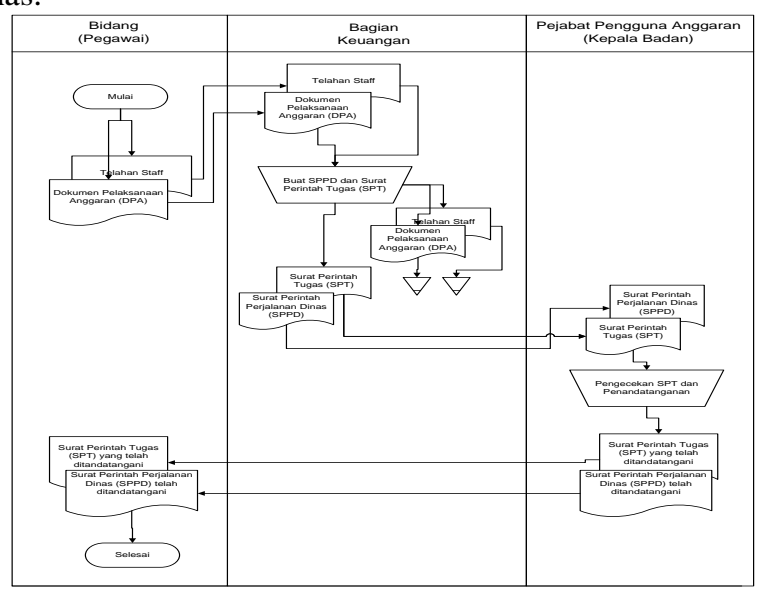

Gambar 2. FOD Yang Berjalan

\section{Flow Of Document (FOD) Yang Diusulkan}

Pada entitas bidang kepegawaian terdiri dari lima penginputan, penginputan yang pertama adalah input data pegawai dimana pegawai menginputkan data pegawai kemudian diproses lalu disimpan dalam 
tabel database pegawai, penginputan yang kedua adalah input kegiatan,pada penginputan ini dimana datanya diambil dari database data pegawai dan database biaya kemudian dilakukan proses setelah itu disimpan didalam database kegiatan, yang ketiga adalah input transport dimana pada penginputan ini datanya diperoleh dari database biaya kemudian dilakukan proses dan disimpan didalam database biaya, yang keempat adalah input pejabat, pada penginputan ini data yang diinput diperoleh dari database pegawai, kemudian diproses lalu disimpan dalam tabel database pejabat, yang kelima adalah input SPPD dimana data yang diinput diperoleh dari database pegawai, kegiatan, transport, pejabat dan database biaya, kemudian diproses dan disimpan dalam tabel database SPPD, kemudian dari database SPPD dilakukan proses cetak dan menghasilkan laporan SPPD yang mana laporan tersebut akan diberikan kepada entitas bagian pejabat pengguna anggaran (kepala badan)

Pada entitas bagian keuangan menginputkan biaya dan kemudian dilakukan proses lalu disimpan dalam tabel database referensi biaya, kemudian untuk proses rincian biaya data diperoleh dari database referensi biaya kemudian diproses dan menghasilkan laporan rincian biaya. Pada entitas bagian pejabat pengguna anggaran dapat melihat data SPPD yang diperoleh dari database SPPD dan menerima hasil laporan SPPD dari entitas bidang kepegawaian, kemudian laporan tersebut diarsipkan di entitas pejabat pengguna anggaran.

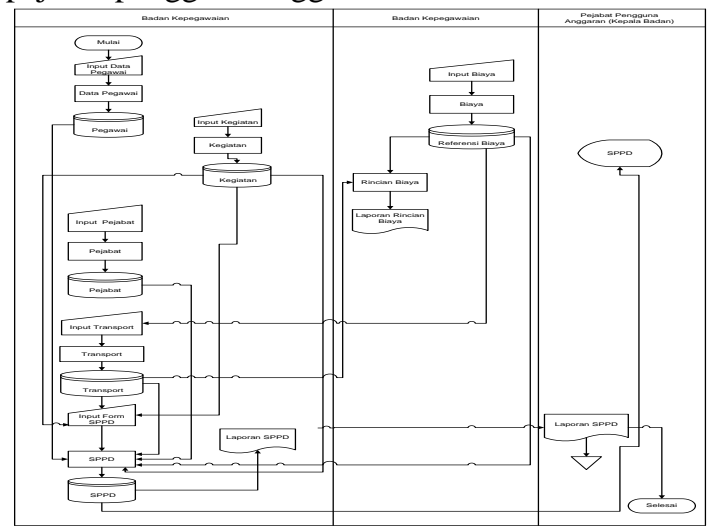

Gambar 3. FOD Yang Diusulkan

\section{Context Diagram}

Entitas penting yang berperan penting untuk menerbitkan surat perintah perjalanan dinas, yaitu bidang kepegawaian, bidang keuangan dan pejabat pengguna anggaran, untuk lebih jelasnya dapat diuraikan sebagai berikut :

1. Bidang kepegawaian menginputkan data pegawai, data kegiatan, data transport, data penandatangan, dan data SPPD, kemudian kelima data tersebut diberikan ke sistem.

2. Bidang keuangan menginputkan data biaya kemudian diberikan ke sistem, dan menerima laporan rincian biaya yang dihasilkan dari sistem

3. Pejabat pengguna anggaran (kepala badan) menerima laporan SPPD yang dihasilkan dari sistem.

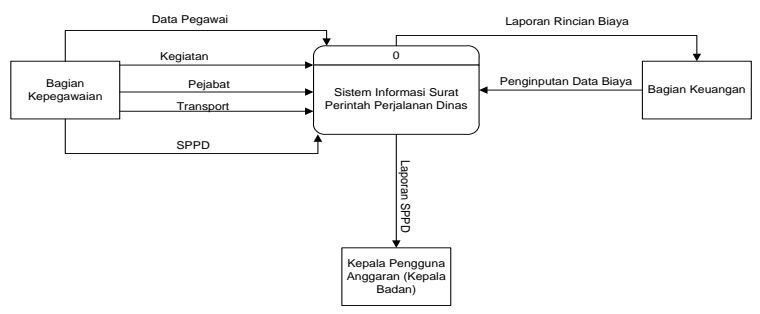

Gambar 4. Context Diagram

\section{Data Flow Diagram (DFD) Level 0}

Proses yang pertama adalah proses pegawai, proses ini mendapatkan data pegawai dari entitas bidang kepegawaian, dari proses yang dihasilkan akan disimpan dalam datastore pegawai.

Proses yang kedua adalah proses kegiatan, proses ini mendapatkan data dari entitas bidang kepegawaian dan juga membaca data dari datastore pegawai dan datastore biaya, dari proses kegiatan data yang dihasilkan akan disimpan dalam datastore kegiatan.

Proses yang ketiga adalah proses transport, proses ini mendapatkan data dari entitas bidang kepegawaian dan juga membaca data dari datastore biaya, dari proses transport data yang dihasilkan akan disimpan dalam datastore transport.

Proses yang keempat adalah proses pejabat, proses proses ini mendapatkan data dari entitas bidang kepegawaian dan juga membaca data dari datastore pegawai, dari proses pejabat data yang dihasilkan akan disimpan dalam datastore pejabat. Proses yang kelima adalah proses SPPD, proses proses ini mendapatkan data dari entitas bidang kepegawaian dan juga membaca data dari datastore pegawai, datastore kegiatan, datastore transport, datastore pejabat dan datastore biaya, dari proses SPPD data yang dihasilkan akan disimpan dalam datastore SPPD.

Proses yang keenam adalah proses entry biaya, proses ini mendapatkan data dari entitas bidang keuangan, dari proses entry biaya data yang dihasilkan akan disimpan dalam datastore biaya

Proses yang ketujuh adalah proses laporan, pada proses iniakan menghasilkan dua laporan laporan yang pertama adalah laporan SPPD,laporan ini mendapatkan data dari datastore pegawai, datastore kegiatan, datastore transport, datastore pejabat, datastore SPPD, dan datastore biaya. Kemudian dari proses laporan akan menghasilkan laporan SPPD yang akan diberikan pada entitas bagian pejabat pengguna anggaran (kepala badan). Yang kedua adalah laporan rincian biaya, laporan ini mendapatkan data dari datastore pegawai, datastore transport, dan datastore biaya, kemudian dari proses laporan akan menghasilkan laporan rincian biaya yang akan diberikan pada entitas bagian keuangan. 


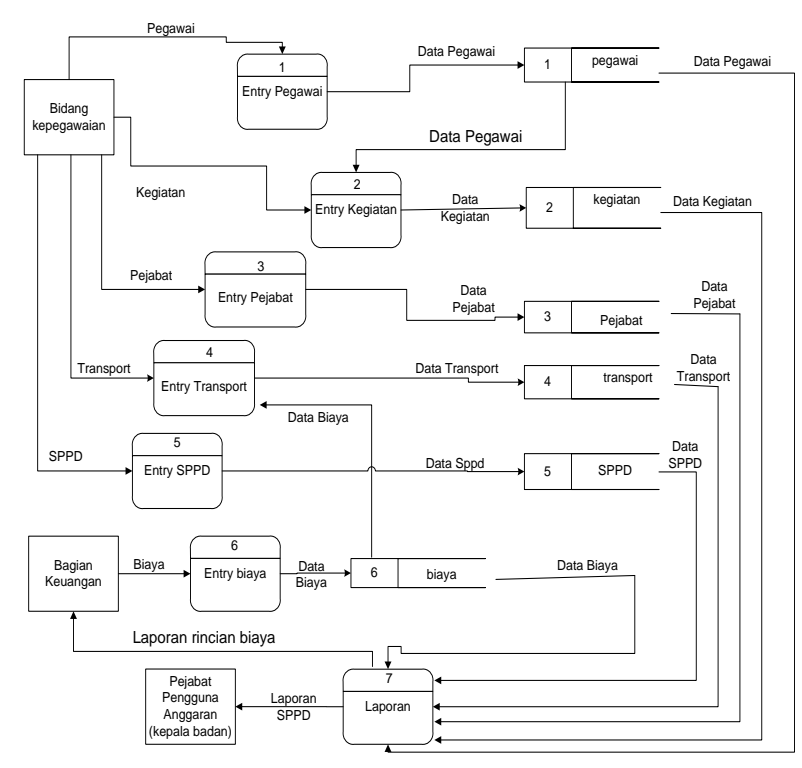

Gambar 5. Data Flow Diagram (DFD) Level 0

\subsection{Entity Relationship Diagram (ERD)}

Entitas Pegawai memiliki relasi dengan entitas sppdmain yaitu atribut Nip dengan ketentuan satu atribut Nip pada entitas sppdmain mempunyai banyak atribut Nip pada entitas Pegawai. Entitas sppdmain memiliki relasi dengan entitas sppddt yaitu atribut tahun dan atribut nosppd dengan ketentuan satu atribut tahun dan atribut nosppd pada entitas sppdmain mempunyai banyak atribut tahun dan atribut nosppd pada entitas sppddt.

Entitas ref_kegiatan memiliki relasi dengan entitas sppdmain yaitu atribut tahun dan atribut kdgiat dengan ketentuan satu atribut tahun dan atribut kdgiat pada entitas sppdmain mempunyai satu atribut tahun dan atribut kdgiat pada entitas ref_kegiatan.

Entitas ref_biaya memiliki relasi dengan entitas sppdmain yaitu atribut tahun dan atribut kodebiaya dengan ketentuan satu atribut tahun dan atribut kodebiaya pada entitas sppdmain mempunyai satu atribut tahun dan atribut kodebiaya pada entitas ref_biaya.

Entitas ref_angkutan memiliki relasi dengan entitas sppdmain yaitu atribut tahun dan atribut kdangkutan dengan ketentuan satu atribut tahun dan atribut kdangkutan pada entitas sppdmain mempunyai satu atribut tahun dan atribut kdgiat pada entitas ref_angkutan

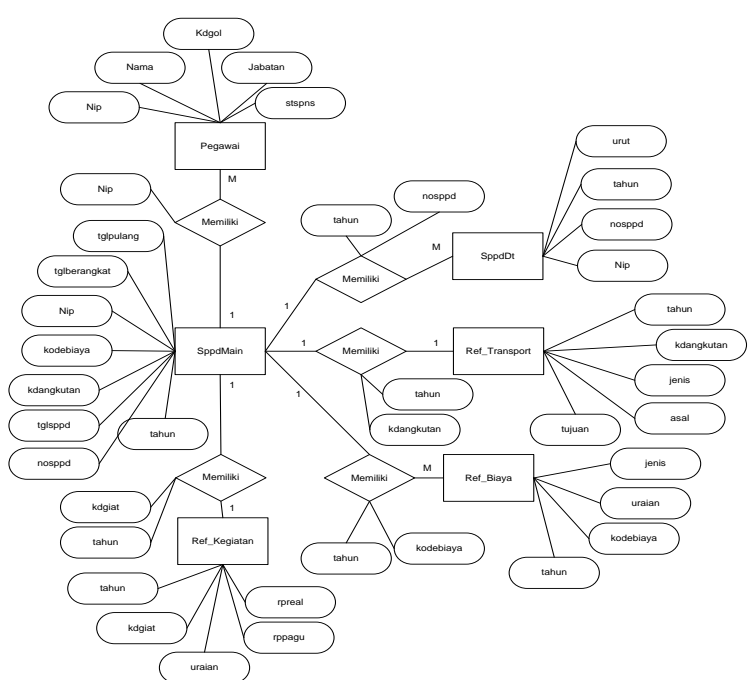

Gambar 6. Entity Relationship Diagram (ERD) Sistem Informasi SPPD

\section{IMPLEMENTASI}

Pada tahap ini, hasil dari tahap perancangan diterjemahkan ke dalam bahasa pemrograman. Wujud dari hasil tahap implementasi ini nantinya adalah sebuah sistem yang siap untuk diuji.

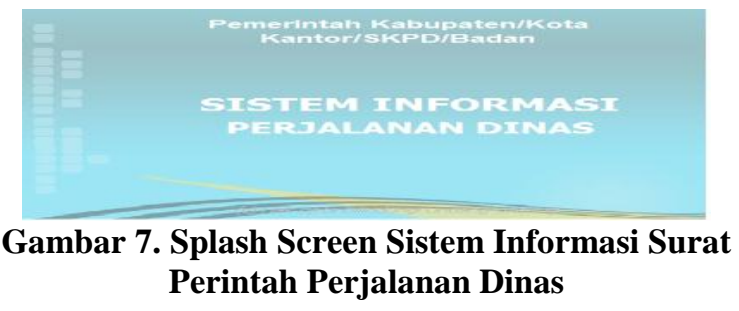

Gambar 7 merupakan gambar form awal aplikasi yang menginformasikan nama sistem beserta versi pembuatan sistem.

\section{Form Login}

Pada halaman ini, user diminta untuk memasukan tahun anggaran yang berjalan, username dan kata sandi. Username dan tahun anggaran dapat dipilih, agar memudahkan user login ke sistem, kemudian tekan tombol LANJUT untuk melakukan verifikasi tahun anggaran, username dan kata sandi. Jika anda menekan tombol BATAL untuk membatalkan proses login dan keluar dari aplikasi.

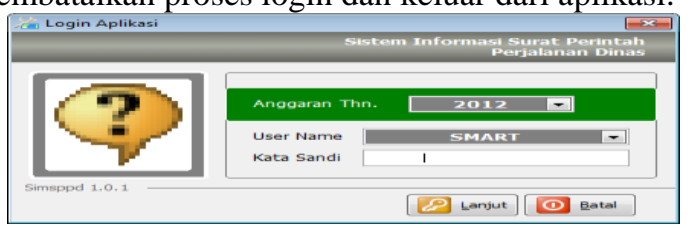

Gambar 8. Halaman Login

2. Pesan Kesalahan Login

Pesan ini muncul jika user salah memasukan username dan atau kata sandi sehingga anda tidak dapat login kedalam sistem. Seperti pada gambar 4.8 sebagai berikut. 


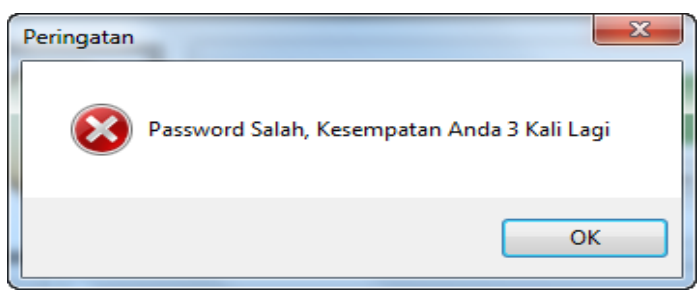

Gambar 9. Pesan kesalahan login sistem

Anda diberikan 3 (tiga) kali kesempatan mengulangi kembali, memasukan user name dan password dengan benar.

\section{Form Utama Menu Administrator}

Jika user yang melakukan proses login adalah Administrator maka akan muncul halaman utama Menu Sistem Informasi berisi tabel-tabel referensi Perjalanan dinas. Transaksi surat perintah perjalaan dinas yang terdiri dari beberapa sub menu yaitu data pegawai, data surat perintah tugas dan data surat perintah perjalanan dinas. Menu laporan merupakan himpunan laporan yang dibuat setelah pelaksanaan perjalanan dinas. Menu pengaturan yaitu menu yang berfungsi untuk mengatur sistem diantaranya, sub menu user, sub menu konfigurasi sistem, sub menu pengturan printer, sub menu optimalisasi database.

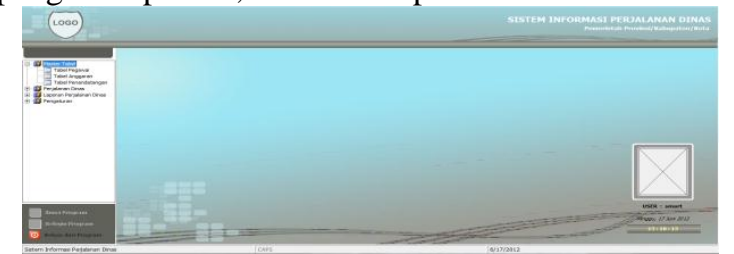

\section{Gambar 10. Form Menu Utama Sistem Informasi Perjalanan Dinas}

\section{Form Konfigurasi Sistem informasi perjalanan} dinas

Form ini merupakan form yang digunakan untuk menampung informasi satuan kerja perangkat daerah (SKPD), versi pembuatan sistem informasi, dan alamat keberadaan SKPD. Data pada konfigurasi sistem ini nantinya selalu digunakan dalam membuat laporan, sehingga form konfigurasi ini harus di isi dengan benar. Berikut gambar form konfigurasi sistem informasi perjalanan dinas

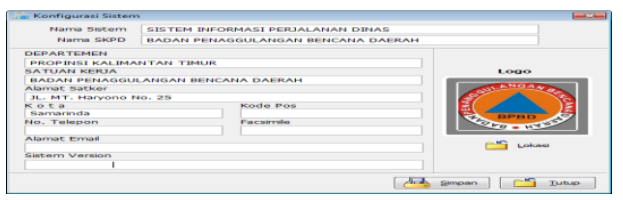

Gambar 11 Form Konfigurasi sistem

\section{Form Input Kegiatan}

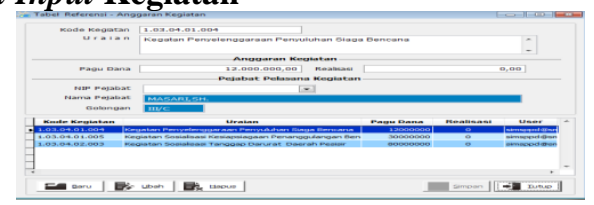

Gambar 12. Form Input Kegiatan

Pada gambar 4.24 adalah form untuk memuat data kegiatan yang berhubungan dengan perjalanan dinas dalam dan luar daerah.

\section{Form Data Pegawai}

Pada halaman ini adalah listing untuk menampilkan seluruh data pegawai yang terekam dalam tabel pegawai. Anda dapat menggunakan pencarian yang dapat melakukan pencarian berdasarkan nama ataupun berdasarkan Nomor Induk Pegawai secara otomatis.

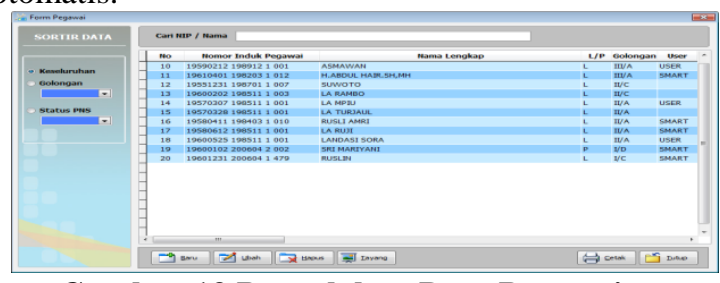

\section{Gambar 13.Pengolahan Data Pegawai}

Tombol baru digunakan untuk masuk form tambah data pegawai baru, tombol ubah untuk mengubah data pegawai jika terjadi kesalahan sewaktu merekam data pegawai, hapus data, digunakan untuk menghapus data pegawai. Dan tayang untuk menampilkan data rincian pegawai. Apabila telah selesai mengisikan data pegawai dan ingin keluar dari form ini, dapat dengan mengklik tombol tutup.

7. Form Pengisian Data Pegawai (Proses Tambah) Pada halaman ini user diminta untuk memasukan data pegawai. Tekan tombol Simpan untuk menyimpan data pegawai atau tekan tombol Batal untuk membatalkan proses penyimpanan.

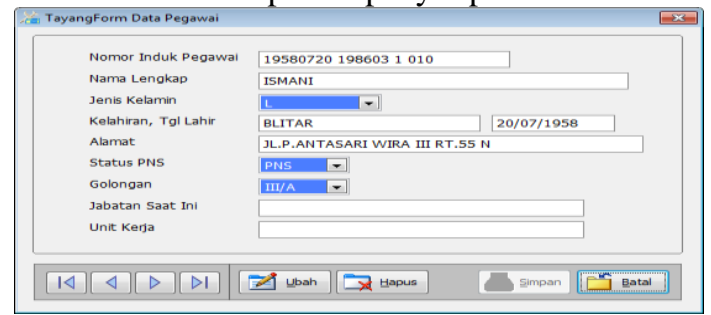

Gambar 14. Isi Data Pegawai

Anda dapat menggunakan tombol navigasi untuk melihat data pegawai satu-persatu secara bergantian dan terperinci. Tombol simpan akan aktif jika anda akan melakukan perubahan data ataupun tambah data baru. Tombol simpan akan berubah menjadi tombol hapus jika anda ingin menghapus data pegawai. Jika anda ingin membatalkan atau keluar dari form ini, dengan mengklik tombol batal, dan akan kembali ke form listting pegawai.

\section{Form Biaya Transport}

Pada halaman ini user bisa melakukan proses tambah, edit dan hapus data biaya transportasi, seperti pada gambar 4.27 berikut :

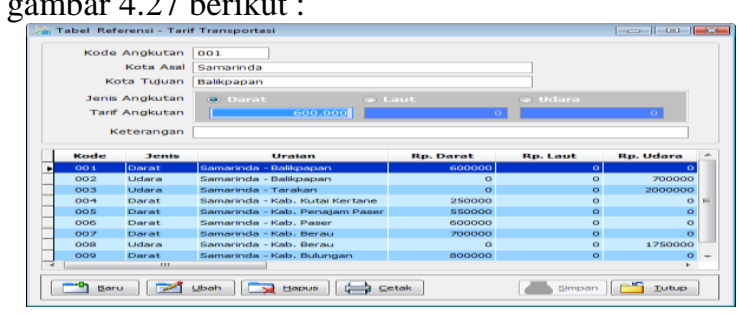

Gambar 15. Form biaya transport

Form ini memiliki fasilitas beberapa tombol diantaranya Tombol baru digunakan untuk masuk 
form tambah data biaya transport, tombol ubah untuk mengubah biaya transportasi jika terjadi kesalahan sewaktu merekam biaya transport hapus data, digunakan untuk biaya transport.

\section{Form pejabat penandatangan}

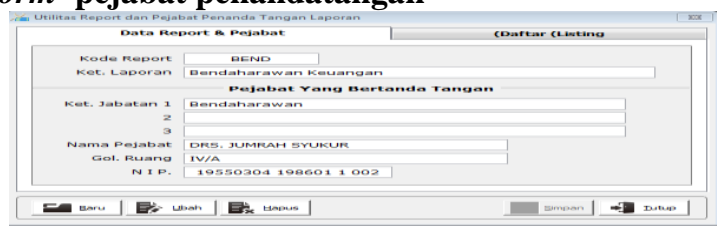

Gambar 16. form pejabat penandatangan

Seperti yang terlihat pada gambar form 4.28 pejabat penandatangan digunakan untuk menginputkan data pejabat penandatangan berupa kode report, keterangan laporan, keterangan jabatan, nama pejabat, golongan ruang, nip dan juga digunakan jika terjadi penambahan data pejabat, perubahan data pejabat, menghapus data pejabat, dan menyimpan data pejabat. Data pejabat penandatangan akan tersimpan langsung tersimpan pada tabel pejabat

10. Form Biaya

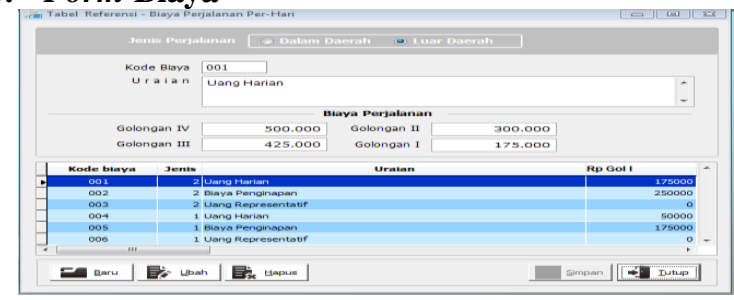

Gambar 17. form biaya

Seperti yang terlihat pada gambar form 4.29 kegiatan digunakan untuk menginputkan data kegiatan berupa kode biaya, uraian, golongan dan juga digunakan jika terjadi penambahan data kegiatan, perubahan data kegiatan, menghapus data kegiatan, dan menyimpan data kegiatan. Data kegiatan akan tersimpan langsung tersimpan pada tabel kegiatan.

12 Tampilan Form Laporan SPPD

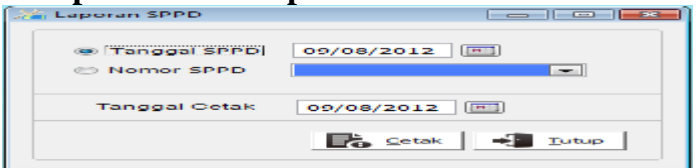

Gambar 18. Form Laporan SPPD

Tampilan form 4.30 laporan SPPD di gunakan untuk mencetak laporan surat perjalanan dinas (SPPD) berdasarkan kriteria tanggal dan kriteria nomor SPPD

\section{Tampilan Form Rincian Biaya}

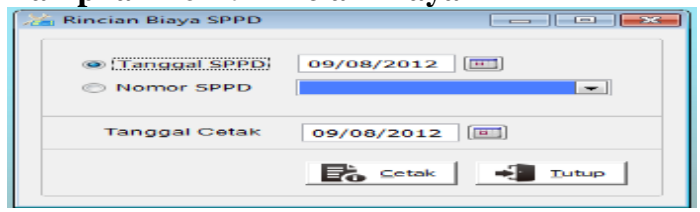

Gambar 19. Form Rincian Biaya

Tampilan form laporan rincian biaya di gunakan untuk mencetak laporan rincian biaya berdasarkan kriteria tanggal dan kriteria nomor SPPD.

\section{Halaman Pengolahan Data $U$ ser}

Pada halaman ini user bisa melakukan proses tambah, edit, hapus dan cari user.

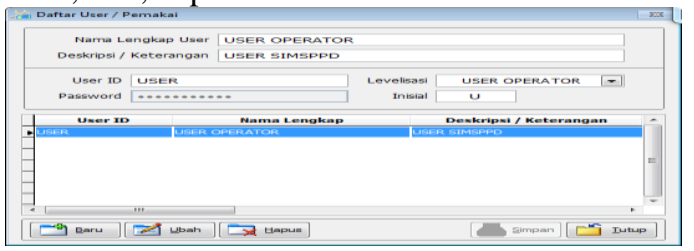

Gambar 20.Form manajemen user

Pada halaman ini user diminta untuk memasukan data user. Tekan tombol Simpan untuk menyimpan data user atau tekan tombol Batal untuk membatalkan proses penyimpanan.

15 Halaman Laporan Surat Perjalanan dinas

Setelah melakukan pengisian data surat perintah perjalanan dinas, dan data telah berhasil di rekam dalam database, selanjutnya melakukan pencetakan surat perintah perjalanaan dinas dengan mengklik tombol cetak dengan icon bergambar printer yang dapat dilihat pada gambar 4.32. sebagai berikut :

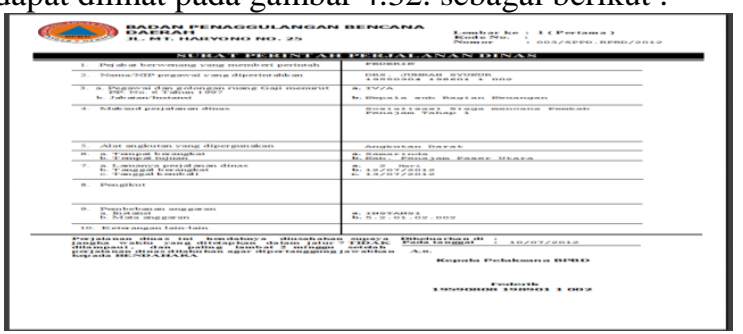

Gambar 21. Halaman Cetak Surat Perintah Perjalanaan Dinas Halaman Depan

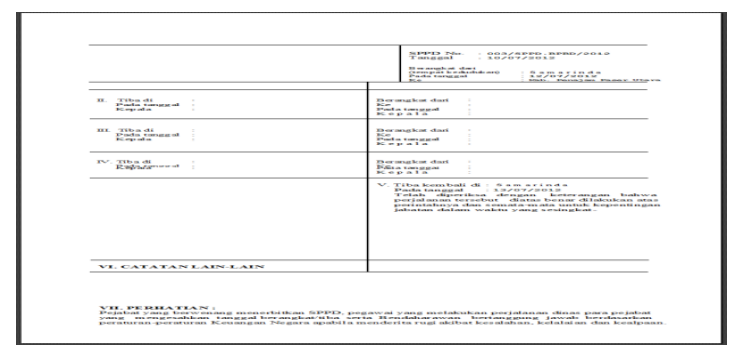

Gambar 22. Halaman Cetak Surat Perintah Perjalanaan Dinas Halaman Belakang

Untuk mencetak keprinter dapat langsung mengklik tombol printer pada sisi sudut kanan atas, ataupun jika ingin menutup lembar tersebut dengn mengklik icon close.

16 Rekapitulasi Perjalanan Dinas

REKAPITULASI SPPD

Tanggal Cetak : 06 Agustus 2012

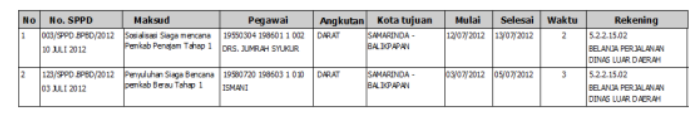

Gambar 23. Cetak Rekapitulasi Perjalanaan Dinas 
2. Rincian Biaya Perjalanaan Dinas

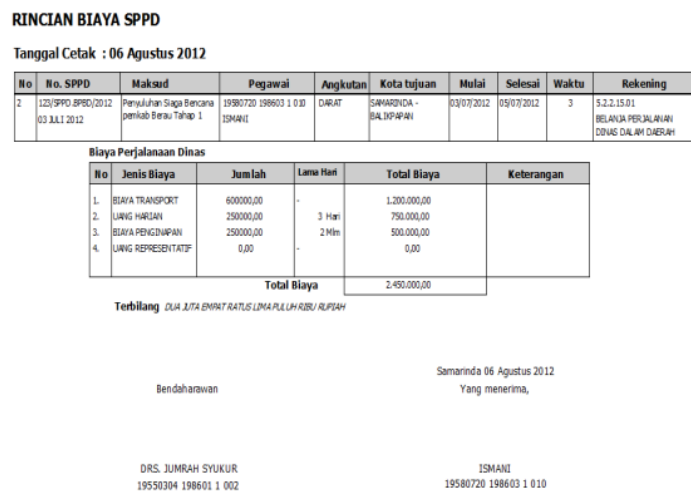

Gambar 24. Cetak Rincian Biaya Perjalanaan Dinas

\section{KESIMPULAN}

Dengan adanya sistem informasi surat perjananan dinas pada Badan Penanggulangan Bencana Daerah (BPBD) Provinsi Kalimantan Timur dapat mengefisiensikan waktu pembuatan surat perjalanan dinas dan mudah dalam memanajemen anggaran perjalanan dinas. Penggunaan LAN juga dapat mudahkan dan memanajemen user pada saat mengoperasikan sistem informasi perjalanan dinas ini.

Setiap pegawai yang melaksanakan perjalanan dinas sesuai dengan kegiatan yang telah direncanakan sebelumnya dan berdasarkan plafon anggaran belanja perjalanan dinas.

Akurasi data realisasi perjalanan dinas pada Badan Penanggulangan Bencana Daerah (BPBD) Provonsi Kalimantan Timur dapat dipertanggung jawabkan kepada pihak yang berwenang memeriksa penggunaan dana perjalanan dinas, dan tersimpan sehingga sewaktuwaktu dapat dipergunakan sesuai kebutuhan

\section{SARAN}

Diharapkan program ini dapat dikembangkan berbasis web, sehingga dapat di akses secara luas dan penggunaan dana perjalanan dinas jadi lebih transparan.

Hendaknya dalam pengembangan sistem informasi perjalanan dinas ini perlu diperhatikan modul realisasi agar tidak terjadi kelebihan pagu dana anggaran belanja perjalanan dinas yang dapat menyebabkan kerugian negara.

\section{DAFTAR PUSTAKA}

Fathansyah. 2005, Buku Teks Komputer Basis Data, Penerbit Informatika, Bandung

Jogiyanto.HM, 2005, Analisis dan Desain Sistem Informasi, Andi Yogyakarta, Yogyakarta

Kadir Abdul, 2008, Konsep \& Tuntunan Praktis Basis Data, Penerbit Andi Yogyakarta

Kristanto andri, 2003, Perancangan Sistem Informasi dan Aplikasinya, Yogyakarta: gava media.
Madcoms, 2008, Microsoft Visual Basic 6.0 dan Cristal Report 2008 , Penerbit Andi.

Pressman, Roger S, 2002, Rekayasa Perangkat Lunak : pendekatan praktisi (buku I), Yogyakarta : Andi

Ramadhan, Arief, 2004, 36 Jam Belajar Visual Foxpro 8.0, Jakarta : PT. Elex Media Komputindo.

Suarna, 2007 Petunjuk Teoritis Pengantar LAN, Pengenalan jaringan, Penerbit Informatika, Bandung 